$\underline{\text { Original Article }}$

\title{
Clinical Significance of Assessment of Thrombospondin and Placenta Growth Factor Levels in Patients with Sickle Cell Anemia: Two Centers Egyptian Studies
}

\author{
Adel A Hagag, ${ }^{1}$ Ghada Elmashad ${ }^{3}$ and Aml Ezzat Abd El-Lateef ${ }^{2}$ \\ ${ }^{1}$ Pediatrics Department , ${ }^{2}$ Clinical Pathology Department, Faculty of Medicine, Tanta University, Egypt \\ ${ }^{3}$ Pediatric Department, Faculty of Medicine, Elmenofia University, Egypt
}

Correspondance to: Adel A Hagag. E-mail: adelhagag20@yahoo.com

Competing interests: The authors have declared that no competing interests exist.

Published: July 1, 2014

Received: March 5, 2014

Accepted: June 20, 2014

Citation: Mediterr J Hematol Infect Dis 2014, 6(1): e2014044, DOI: 10.4084/MJHID.2014.044

This article is available from: http://www.mjhid.org/article/view/13060

This is an Open Access article distributed under the terms of the Creative Commons Attribution License (http://creativecommons.org/licenses/by/2.0), which permits unrestricted use, distribution, and reproduction in any medium, provided the original work is properly cited.

\begin{abstract}
.
Background: Sickle cell disease has a worldwide distribution. Vaso-occlusive crisis (VOC) is one of the most important clinical features of the disease. Thrombospondin (TSP1) and Placenta growth factor (PIGF) have been reported to be involved in sickle cell diseases (SCD).

Objective: The aim of this study was to assess the clinical significance of Thrombospondin and Placenta growth factor profiles in patients with sickle cell disease.

Patients and methods: This study was carried out in sixty patients with sickle cell anemia who were attendants to Hematology units, Pediatric Departments, Tanta and Elmenofia University Hospitals in the period between December 2011 and May 2014 including thirty patients during vaso-occlusive crisis and thirty patients out of crisis. Also this study included twenty healthy children of matched age and sex as a control group. Serum TSP1 and PIGF levels were analyzed by ELISA.

Results: In SCA patients with crisis the mean serum Thrombospondin level was 902.5 \pm 280.89 $\mathrm{ng} / \mathrm{mL}$; in SCA patients out of crisis the mean serum Thrombospondin level was $462.5 \pm 190.2$ $\mathrm{ng} / \mathrm{mL}$ and in controls the mean value was $236.66 \pm 58.29 \mathrm{ng} / \mathrm{mL}$. In SCA patients with crisis the mean serum Placenta growth factor level was $19.97 \pm 1.28 \mathrm{pg} / \mathrm{ml}$; in SCA patients out of crisis the mean serum Placenta growth factor level was $13.12 \pm 1.82 \mathrm{pg} / \mathrm{ml}$ and in controls the mean value was $9.89 \pm 1.20 \mathrm{pg} / \mathrm{ml}$. All paired comparisons for Thrombospondin and Placenta growth factor reached statistical significance $(P<\mathbf{0 . 0 0 1})$. There was significant positive correlation between serum Thrombospondin and Placenta growth factor levels in sickle cell anemia patients during crisis $(\mathrm{r}=0.848, \mathrm{p}=<0.001)$.

Conclusions: This is the first study to show TSP1and PIGF concentration changes in patients with SCD in a large cohort study from Middle East, and to show correlation between both markers; therefore TSP1and PIGF may be useful VOC markers in SCD patients.

Recommendation: To further assess TSP1 and PIGF as a marker of VOC in patients with SCD, further studies should be conducted to determine the exact point before VOC, when serum TSP1
\end{abstract}




\section{and PIGF levels begin to increase. This requires monitoring of the TSP1 and PIGF levels in sickle cell patients out of crisis, showing how rapidly these levels increase just before VOC development.}

Introduction. Sickle cell disease (SCD) is hereditary hemoglobinopathy characterized by abnormal hemoglobin production, hemolytic anemia, and intermittent occlusion of small vessels, leading to acute and chronic tissue ischemia, chronic organ damage, and organ dysfunction. ${ }^{1}$ Sickle hemoglobin $(\mathrm{Hb} \mathrm{S})$ is common and clinically significant hemoglobin structural variant. $^{2}$

$\mathrm{Hb} \mathrm{S}$ is caused by $\beta$-globin gene mutation in which the $17^{\text {th }}$ nucleotide is changed from thymine to adenine and the $6^{\text {th }}$ amino acid in the $\beta$-globin chain becomes valine instead of glutamic acid; this mutation produces a hydrophobic motif in the deoxygenated $\mathrm{Hb} \mathrm{S}$ tetramer that results in binding between $\beta_{1}$ and $\beta_{2}$ chains of two hemoglobin molecules. This crystallization produces a polymer nucleus, which grows and fills the erythrocyte, disrupting its architecture and flexibility and promoting cellular dehydration. ${ }^{3}$ Damage to the erythrocyte cell membrane occurs as it passes through the microcirculation, shortening its life span and causing chronic hemolytic anemia.${ }^{1}$ Also $\mathrm{Hb} \mathrm{S}$ polymerizes when sickle RBCs are exposed to hypoxic conditions in the microcirculation, leading to increased cellular adhesiveness, nitric oxide depletion and vaso-occlusion. ${ }^{4}$ Most patients will have severe pain due to occlusion of blood flow to bones, muscles, arms, legs, back, abdomen, and chest. ${ }^{5}$

Cytokines and adhesion molecules play an important role in the pathophysiology of vasoocclusion in SCD. ${ }^{6}$ Placenta growth factor (PIGF) is released by immature erythrocytes and is elevated in SCD and may play a role in the pathophysiology of sickle cell disease-associated pulmonary hypertension by inducing the release of vasoconstrictor substance called endothelin- $1 .^{7}$

Platelets are activated in SCD particularly during vaso-occlusive episodes (VOE). ${ }^{8}$ Increased platelet activation likely plays a catalytic role in vaso-occlusion and vasculopathy in $\mathrm{SCD}^{9,10}$ by increasing the adhesion of sickle RBCs to the endothelium ${ }^{11}$ via secretion of fibrinogen, von Willebrand Factor $^{12}$ and Thrombospondin-1 (TSP1) ${ }^{13}$ and promoting further intimal damage. ${ }^{14}$

TSP1 is multifunctional glycoprotein containing domains for adhesive proteins, enzymes, cell receptors that is abundantly present in platelet $\alpha$-granules, and is a key player in vascular biology. ${ }^{15}$ TSP1 is the major secretory product of activated platelets, which is increased in VOE. ${ }^{8}$ TSP1, via its cognate receptor CD47, modulates vascular responses to hypoxia, regulates vaso-constriction, inhibits angiogenesis, and promotes adhesion of sickle RBCs to the endothelium. ${ }^{16}$ Moreover, TSP1 inhibits NO signaling pathway through binding to the receptors CD36 and CD47 expressed on endothelial cells and platelets ${ }^{(17,18)}$ thus; TSP1 represents a plasma biomarker of disease severity in SCD. ${ }^{8}$

Aim of this Study. The aim of this study was to assess the clinical significance of Thrombospondin and Placenta growth factor profiles in patients with sickle cell disease during crisis and in steady state.

Patients and Methods. This study was done after approval from ethical committee of research center in Tanta and Elmenofia University Hospitals and informed written parental consent from every case that participates in this research and was carried out on 60 cases with sickle cell disease (HbSS) who were admitted or under follow up at Hematology unit, Pediatric department, Tanta and Elmenofia University Hospitals in the period between December 2011 and May 2014, including thirty patients with sickle cell anemia during vaso-occlusive crisis (18 males and 12 females) and thirty patients in steady state out of crisis (15 males and 15 females). Also this study included twenty healthy children of matched age and sex as a control group. To ensure that the patients is not in crisis samples were obtained from patients who had no acute sickle events, fever, or infections 3 weeks before or 3 weeks after the blood sample and were not transfused within the last 90 days. ${ }^{19}$ Vaso-oclusive crisis is acute painful condition at any site of the patient's body due to occlusion of blood flow to bones, bone marrow, muscles, organs, arms, legs, back, abdomen, or chest ${ }^{5}$.' For all patients the following were done:

- Complete history taking

- Thorough clinical examination with especial account on pallor, jaundice, leg ulcers, hepatomegaly and splenomegaly.

- Laboratory investigations including:

a) Complete blood count. One $\mathrm{ml}$ of venous blood were collected using sterile needles through gentle venipuncture after sterilization of site of puncture by alcohol, and collected samples were delivered on $20 \mathrm{uL}$ EDTA solution for complete blood count including reticulocytic count and differential count which was done on leishman stained peripheral blood smear with evaluation using ERMA PCE-210 $\mathrm{N}$ cell -counter. ${ }^{20}$

b) Serum thrombospondin levels. Two $\mathrm{ml}$ of venous blood samples from patients and controls 
were collected in citrated tubes and immediately transferred to laboratory at $4^{\circ} \mathrm{C}$. The tubes were inverted 8-10 times and then subjected to double centrifugation at $1500 \mathrm{~g}$ at $4^{\circ} \mathrm{C}$ to obtain platelet poor plasma (PPP). The supernatant was aliquoted into cryotubes and stored at $-80^{\circ} \mathrm{C}$ until the day of testing by ELISA. PPP were thawed and assessed for levels of TSP1 by ELISA in duplicate (R\&D Systems, Minneapolis, MN). ${ }^{8}$

c) Serum placenta growth factor levels. Two $\mathrm{ml}$ of Heparinized venous blood samples was obtained from patients with SCD and healthy controls. The blood samples were centrifuged at $0^{\circ} \mathrm{C}-4^{\circ} \mathrm{C}$ and $1000 \mathrm{~g}$ for 15 minutes and plasma was separated within 2 hours of sample collection and stored at $80^{\circ} \mathrm{C}$ until it was assayed. PlGF concentration was determined on cell-free heparinized plasma using ELISA. ${ }^{19}$

Statistical analysis. Data were collected and analyzed using SPSS for windows (version 12). All Data were expressed as in terms of mean values \pm SD. Comparisons of parameters among groups were made using the paired $t$ test. Two-group comparisons were performed non-parametrically using the Mann-Whitney U test. All statistical tests were two tailed, and $P<0.05$ was considered statistically significant.
Results. There were no statistically significant differences between sickle cell anemia patients with and without vaso-occlusive crisis as regards age, sex, pallor, jaundice, leg ulcers, hepatomegaly and splenomegaly (Table 1).

There were statistically significant differences between patients with or without VOC and control group as regards platelets; RBCs and WBCs but there were no statistically significant differences between patients with and without VOC (Table 2).

Mean serum Thrombospondin levels were significantly higher in sickle cell anemia patients with crisis than those out of crisis and were significantly higher in sickle cell anemia patients with or without crisis than control group (Table 3).

Mean serum Placenta growth factor levels were significantly higher in sickle cell anemia patients with crisis than sickle cell anemia patients out of crisis and were significantly higher in SCA patients with or without crisis than controls (Table 3).

Significant positive correlation was found between serum Thrombospondin and Placenta growth factor levels in sickle cell anemia patients during crisis (Figure 1).

Discussion. Sickle cell disease is one of the most important single gene disorders of human beings ${ }^{21}$ that

Table 1: Clinical data of studied patients with sickle cell disease.

\begin{tabular}{|l|c|c|c|}
\hline Patients data & $\begin{array}{c}\text { Sickle cell anemia (HbSS) with VOC } \\
(\mathbf{n = 3 0})\end{array}$ & $\begin{array}{c}\text { Sickle cell anemia (HbSS) out of crisis } \\
(\mathbf{n = 3 0})\end{array}$ & X2 \\
\hline Sex & $18(60 \%)$ & $15(50 \%)$ & 2.99 \\
Males & $12(40 \%)$ & $15(50 \%)$ & 0.39 \\
Females & & & 0.25 \\
Age & $8.86 \pm 2.74(7-11)$ & $10.30 \pm 4.05(8-12)$ & 1.48 \\
Mean age (range) in years & $24(80 \%)$ & $21(70 \%)$ & 0.15 \\
Clinical manifestations & $21(70 \%)$ & $22(73.3 \%)$ & 0.14 \\
Pallor & $23(76.6 \%)$ & $24(80 \%)$ & 0.70 \\
Jaundice & $20(66.6 \%)$ & $19(63.3 \%)$ & 0.26 \\
Hepatomegaly & $2(6.66 \%)$ & $1(3.33 \%)$ & 0.23 \\
Splenomegaly & & 0.88 \\
Leg ulcers & & & 0.11 \\
\hline
\end{tabular}

Table 2. Comparison between sickle cell anemia patients with or without crisis and control group regarding complete blood picture.

\begin{tabular}{|c|c|c|c|}
\hline Parameters & $\begin{array}{c}\text { Sickle cell anemia with VOC } \\
(n=30)\end{array}$ & $\begin{array}{l}\text { Sickle cell anemia out of crisis } \\
(n=30)\end{array}$ & Control $(n=20)$ \\
\hline \multicolumn{4}{|l|}{ WBCS ® } \\
\hline$\overline{\text { Mean (range) }}$ & $11.8 \pm 3.91(6.7-18.5)$ & $10.74 \pm 3.25(7-18)$ & $6.72 \pm 2.51(4-12)$ \\
\hline $\mathrm{T}$ value & $1.12^{\ddagger}$ & $3.44^{\circ}$ & $3.22 *$ \\
\hline$P$ value & $0.96^{*}$ & $0.006^{0}$ & $0.008 *$ \\
\hline \multicolumn{4}{|l|}{ Platelets ® } \\
\hline Mean (range) & $359.6 \pm 32.45(160-650)$ & $357.65 \pm 35.71(170-680)$ & $292 \pm 18.75(150-420)$ \\
\hline $\mathrm{T}$ value & $0.75^{\ddagger}$ & $3.22^{\circ}$ & $4.52 *$ \\
\hline$P$ value & $0.11^{\ddagger}$ & $0.01^{0}$ & $0.03 *$ \\
\hline \multicolumn{4}{|l|}{$\underline{\text { RBCS } \odot ~}$} \\
\hline Mean (range) & $2.3 \pm 0.3(2.3-2-7)$ & $2.57 \pm 0.2(2.3-3)$ & $3.7-4.3)) 3.72 \pm 0.22$ \\
\hline $\mathrm{T}$ value & $0.96^{\ddagger}$ & $2.88^{\circ}$ & $2.66^{*}$ \\
\hline$P$ value & $0.63^{*}$ & $0.028^{0}$ & $0.04 *$ \\
\hline
\end{tabular}

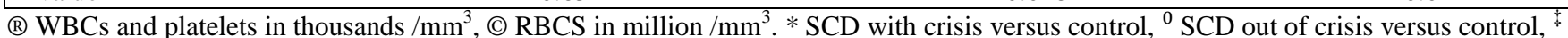
SCD with crisis versus out of crisis. 
Table 3. Comparison between serum levels of Thrombospondin and PIGF in Sickle cell anemia with or without crisis and control group.

\begin{tabular}{|c|c|c|c|}
\hline Parameters & $\begin{array}{l}\text { Sickle cell anemia with VOC } \\
(\mathbf{n}=30)\end{array}$ & $\begin{array}{l}\text { Sickle cell anemia out of crisis } \\
(n=30)\end{array}$ & Control $(\mathbf{n}=\mathbf{2 0})$ \\
\hline \multicolumn{4}{|c|}{ Thrombospondin (ng/mL) } \\
\hline Mean (range) & $902.5 \pm 280.89(400-1450)$ & $462.50 \pm 190.20(190-900)$ & $236.66 \pm 58.29(130-320)$ \\
\hline $\mathrm{T}$ value & $8.83^{\ddagger}$ & $5.93^{\circ}$ & $13.24 *$ \\
\hline$P$ value & $<0.001^{\ddagger}$ & $<0.001^{0}$ & $<0.001 *$ \\
\hline \multicolumn{4}{|l|}{ PIGF (pg/ml) } \\
\hline Mean (range) & $19.97 \pm 1.28(15-23)$ & $13.12 \pm 1.82(11-18)$ & $9.89 \pm 1.20(8-13)$ \\
\hline $\mathrm{T}$ value & $34.37^{*}$ & $16.65^{\circ}$ & $8.21 *$ \\
\hline$P$ value & $<0.001^{\ddagger}$ & $<0.001^{0}$ & $<0.001 *$ \\
\hline
\end{tabular}

* SCD with crisis versus control, ${ }^{0} \mathrm{SCD}$ out of crisis versus control, ${ }^{*} \mathrm{SCD}$ with crisis versus out of crisis.

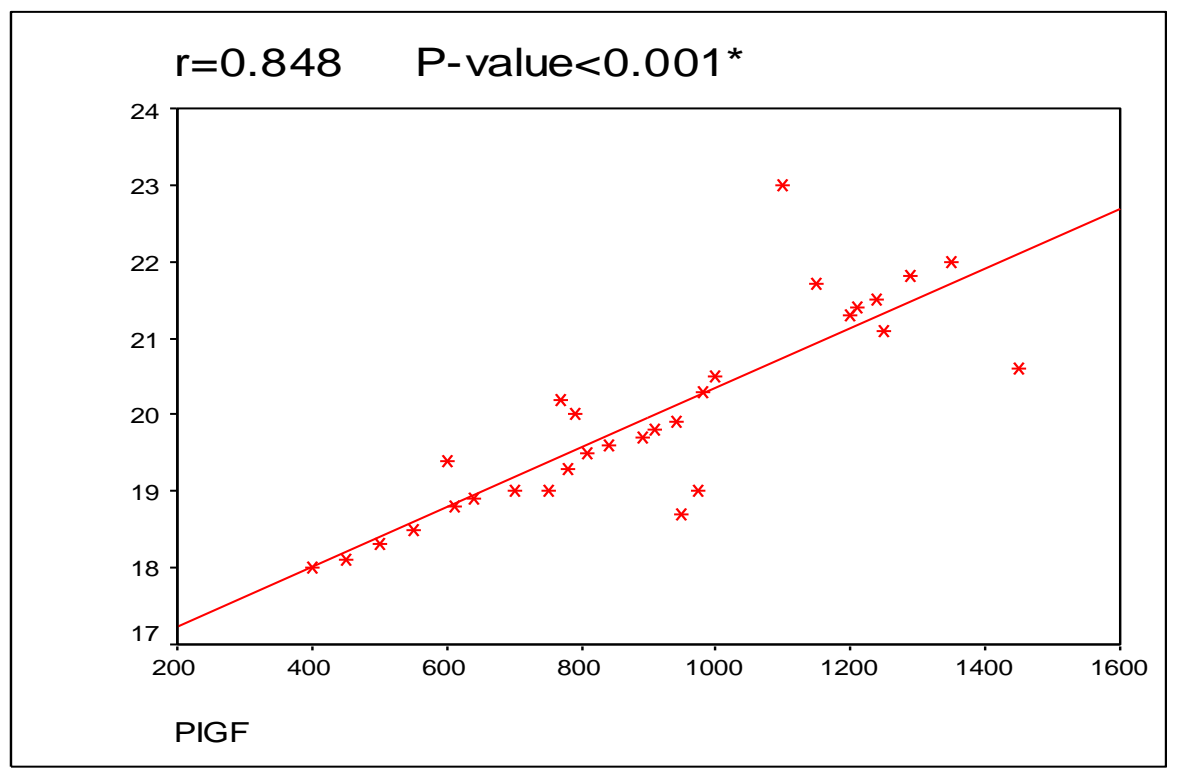

Figure 1. Correlation between thrombospondin and placenta growth factor levels in patients with sickle cell anemia with vasoocclusive crisis.

affects $1 / 400$ individuals of African descent, as well as people of Arab, Indian and Hispanic descents. ${ }^{22}$ VOC has a complex nature, involving interactions between sickle red blood cells, endothelium, and leucocytes. Endothelial damage due to recurrent adhesion of sickle RBCs may disrupt endothelial function, leading to altered cytokine release. Altered balance of proinflammatory and anti-inflammatory cytokines plays an important role in a painful crisis in SCD patients ${ }^{23}$ Placenta growth factor is angiogenic growth factor released by immature erythrocytes and is elevated in SCD. ${ }^{24,25}$ Thrombospondin-1 is the major secretory product of activated platelets and is a key player in vascular biology that is increased in VOE. ${ }^{8,15}$

In this study Thrombospondin and Placenta growth factor were measured by a commercially available ELISA kits in 60 sickle cell disease patients including 30 cases in steady state and 30 cases in a painful crisis compared with 20 normal controls.

In the present study mean, serum Thrombospondin levels were significantly higher in SCA patients with crisis than patients out of the crisis and were significantly higher in SCA patients with or without crisis than controls. This datum was in agreement with Novelli et al $2013^{26}$ who found the same results and Novelli et al $2012^{8}$ who tested 27 patients in steady state and 14 patients with VOE, as well as 17 healthy controls and found the same results with a positive correlation between TSP-1 levels and vaso-occlusive complications and history of acute chest syndrome ${ }^{8}$ and explained this by increased platelet activation and degranulation, that can lead to increased plasma levels of TSP1 in patients with sickle cell anemia with or without crisis, in accordance with a prior study that showed increased platelet activation in VOE. ${ }^{10}$

In the current study placenta, growth factor levels were significantly higher in SCA patients with crisis than patients out of crisis and were significantly higher in SCA patients with or without crisis than controls. This datum was in agreement with Bottomley et al $2000,{ }^{27}$ Natalya et al $2003,{ }^{19}$ Nitin et al $2009^{28}$ and Nitin et al $2010^{29}$ who found significant positive correlation between PIGF concentrations and incidence of VOC and they concluded that PIGF could contribute to vascular occlusion and might modulate clinical severity, since PlGF causes a significant increase in 
proinflammatory cytochemokines mRNA in monocytes. ${ }^{19}$ These proinflammatory molecules contributed to the activation of leukocytes and endothelial cells, a phenomenon observed in SCD at steady state, ${ }^{30}$ and may be responsible for the increased incidence of vascular occlusions in SCD subjects. The leukocytes adhesion to endothelium is a primary event in initiating vascular occlusion and secondarily causes RBCs to adhere to leukocytes or to endothelium. ${ }^{31}$ Brittain et al $2010^{32}$ found significantly elevated PlGF in SCD compared with healthy controls but did not observe any association of PlGF with the frequency of acute pain episodes or history of acute chest syndrome.

In this work, there were significant positive correlations between serum TSP-1 and PlGF levels in patients with sickle cell anemia during vaso-occlusive crisis. This study is, to our knowledge, the first to correlate these two parameters. The significant positive correlation between serum TSP-1 and PIGF levels in this study could be explained by hypoxia, which was shown to be a strong stimulus for angiogenesis in numerous disorders including sickle cell anemia. ${ }^{33}$

\section{References:}

1. Smiley D, Dagogo-Jack S, Umpierrez G. Therapy insight: metabolic and endocrine disorders in sickle cell disease. Nat Clin Pract Endocrinol Metab 2008; 4 (2): 102-109. http://dx.doi.org/10.1038/ncpendmet0702

2. Piel FB, Patil AP, Howes RE, Nyangiri OA, Getting PW, Dewi M, Temperley WH, Williams TN, Weatherall DJ, Hay SI. Global epidemiology of sickle haemoglobin in neonates: a contemporary geostatistical model-based map and population estimates. Lancet 2013 Jan 12; 381(9861):142-51. Epub 2012 Oct 25 http://dx.doi.org/10.1016/S0140-6736(12)61229-X

3. Rees DC, Williams TN, Gladwin MT .Sickle cell disease. Lancet 2010 Dec 11; 376 (9757): 2018-2031. Epub 2010 Dec 3 http://dx.doi.org/10.1016/S0140-6736(10)61029-X

4. Stuart MJ and Nagel RL. Sickle-cell disease. Lancet 2004 Oct 915; 364: 1343-1360. http://dx.doi.org/10.1016/S01406736(04)17192-4

5. Roseff SD. Sickle cell disease: a review. Immuno-hematology 2009; 25(2): 67-74

6. Schnog JB1, Rojer RA, Mac Gillavry MR, Ten Cate H, Brandjes DP, Duits AJ. Steady-state sVCAM-1 serum levels in adults with sickle cell disease. Annals of Hematology 2003 Feb; 82(2):109113. Epub 2003 Feb 11. PMid: 12601490

7. Britain JE, Hulkower B, Jones SK, Strayhorn D, De Castro L, Telen MJ, Orringer EP, Hinderliter A, Ataga KI. Placenta growth factor in sickle cell disease: association with hemolysis and inflammation. Blood 2010 Mar; 115 (10):2014-20. Epub 2009 Dec 29 http://dx.doi.org/10.1182/blood-2009-04-217950

8. Novelli EM, Kato GJ, Ragni MV, Zhang Y, Hildesheim ME, Nouraie M, Barge S, Meyer MP, Hassett AC, Gordeuk VR, Gladwin MT, Isenberg JS. Plasma thrombospondin-1 is increased during acute sickle cell vaso-occlusive events and associated with acute chest syndrome, hydroxyurea therapy, and lower hemolytic rates. American Journal of Hematology 2012; 87 (3): 326-330. http://dx.doi.org/10.1002/ajh.22274

PMid:22318901 PMCid:PMC3619659

9. Hu W1, Jin R, Zhang J, You T, Peng Z, Ge X, Bronson RT, Halperin JA, Loscalzo J, Qin X. The critical roles of platelet activation and reduced NO bioavailability in fatal pulmonary arterial hypertension in a murine hemolysis model. Blood 2010 Sep 2; 116: 1613-1622. Epub 2010 May 28 http://dx.doi.org/10.1182/blood-2010-01-267112

10. Villagra J1, Shiva S, Hunter LA, Machado RF, Gladwin MT, Kato
Hypoxia inducible transcription factors induce the expression of several angiogenic factors including VEGF, nitric oxide synthase, PIGF and TSP $-1 .{ }^{33}$ Both of TSP-1 and PlGF increase together during hypoxia in sickle cell anemia especially in vaso-occlusive crisis. ${ }^{33}$ Also, Placenta growth factor is released by immature erythrocytes and is elevated in SCD due to hyperactive bone marrow. Concomitantly Thrombospondin is released from activated platelets in case of SCD particularly during vaso-occlusive episodes. ${ }^{7,8}$

On the basis of our results, we concluded that the increased TSP1 and PIGF levels could be considered as a marker of VOC in SCD. Further studies should be performed to determine the exact timing of TSP1 and PIGF levels increase, in relation to the episodes of VOC. The monitoring of TSP1 and PIGF levels in patients with sickle cell out of the crisis appears necessary to this scope.

Acknowledgments. we are thankful for the patients of Sickle Cell anemia in Tanta and Elmenofia Hematology Units for participation in this study.
GJ. Platelet activation in patients with sickle disease, hemolysisassociated pulmonary hypertension, and nitric oxide scavenging by cell-free hemoglobin. Blood 2007 Sep 15; 110: 2166-2172. Epub 2007 May 29. http://dx.doi.org/10.1182/blood-2006-12-061697 PMid:17536019 PMCid:PMC1976348

11. Antonucci R, Walker R, Herion J, Orringer E. Enhancement of sickle erythrocyte adherence to endothelium by autologous platelets. Am J Hematol 1990 May; 34: 44-48. http://dx.doi.org/10.1002/ajh.2830340110 PMid:2109530

12. Blann AD1, Marwah S, Serjeant G, Bareford D, Wright J. Platelet activation and endothelial cell dysfunction in sickle cell disease is unrelated to reduced antioxidant capacity. Blood Coagul $\begin{array}{lllll}\text { Fibrinolysis } & 2003 & \text { Apr; } & 14: & \text { 255-259. }\end{array}$ http://dx.doi.org/10.1097/01.mbc.0000061293.28953.8c PMid:12695748

13. Brittain HA1, Eckman JR, Swerlick RA, Howard RJ, Wick TM. Thrombospondin from activated platelets promotes sickle erythrocyte adherence to human microvascular endothelium under physiologic flow: A potential role for platelet activation in sickle cell vaso-occlusion Blood 1993 Apr 15; 81: 2137-2143.

14. Schermuly RT1, Dony E, Ghofrani HA, Pullamsetti S, Savai R, Roth M, Sydykov A, Lai YJ, Weissmann N, Seeger W, Grimminger F. Reversal of experimental pulmonary hypertension by PDGF inhibition. J Clin Invest 2005 Oct; 115: 2811-2821. PMid:16200212 PMCid:PMC1236676

15. Bonnefoy A, Moura R, Hoylaerts MF. The evolving role of thrombospondin-1 in hemostasis and vascular biology. Cell Mol Life Sci 2008 Mar; 65: 713-727. http://dx.doi.org/10.1007/s00018007-7487-y

16. Roberts DD, Miller TW, Rogers NM, Yao M, Isenberg JS. The matri-cellular protein thrombospondin-1 globally regulates cardiovascular function and responses to stress via CD47. Matrix Biol. 2012; 31(3):162-9.

http://dx.doi.org/10.1016/j.matbio.2012.01.005 PMid:22266027 PMCid:PMC3295899

17. Isenberg JS1, Ridnour LA, Perruccio EM, Espey MG, Wink DA, Roberts DD. Thrombospondin-1 inhibits endothelial cell responses to nitric oxide in a cGMP-dependent manner. Proc Natl Acad Sci USA 2005 Sep 13; 102: 13141-13146. Epub 2005 Sep 6 http://dx.doi.org/10.1073/pnas.0502977102 PMid:16150726 PMCid:PMC1201579

18. Isenberg JS1, Ridnour LA, Dimitry J, Frazier WA, Wink DA, 
Roberts DD. CD47 is necessary for inhibition of nitric oxidestimulated vascular cell responses by thrombospondin-1. J Biol Chem 2006 Sep 8; 281: 26069-26080. Epub 2006 Jul 11. http://dx.doi.org/10.1074/jbc.M605040200 PMid:16835222

19. Natalya Perelman, Suresh K. Selvaraj, Sandeep Batra, Lori R. Luck, Anat Erdreich-Epstein, Thomas D. Coates, Vijay K. Kalra, and Punam Malik: Placenta growth factor activates monocytes and correlates with sickle cell disease severity. Blood 2003; 102(4): 1506-1514. http://dx.doi.org/10.1182/blood-2002-11-3422 PMid:12714517

20. Monica C. Strategy of blood safety in Africa region. In: Tito A and Lewis SM (eds). District laboratory practice in tropical countries, 2nd edition. Cambridge low price egyptian edition 2005; chapter 4, P. 268-378.

21. Jastaniah W. Epidemiology of sickle cell disease in Saudi Arabia. Ann Saudi Med 2011; 31(3): 289-293. http://dx.doi.org/10.4103/0256-4947.81540 PMid:21623060 PMCid:PMC3119971

22. Alexya T, Sangkatumvongb S, Connesd P, et al. Sickle cell disease: Selected aspects of pathophysiology. Clin Hemorheol Microcirc 2010; 44(3): doi:10.3233/CH-2010-1270

23. Pathare A1, Al Kindi S, Alnaqdy AA, Daar S, Knox-Macaulay H, Dennison D. Cytokine profile of sickle cell disease in Oman Am. J. Hematol. 2004 Dec; 77:323-328.

24. Tordjman R1, Delaire S, Plouët J, Ting S, Gaulard P, Fichelson S, Roméo PH, Lemarchandel V. Erythroblasts are a source of angiogenic factors. Blood. 2001 Apr; 97: 1968-1974. PMid: 11264160

25. Green CJ, Lichtlen P, Huynh NT, Yanovsky M, Laderoute KR, Schaffner W, Murphy BJ. Placenta growth factor gene expression is induced by hypoxia in fibroblasts: a central role for metal transcription factor-1. Cancer Res. 2001 Mar 15; 61: 2696-2703. PMid:11289150

26. Novelli EM, Kato GJ, , Hildesheim ME, Barge S, Meyer MP, Lozier J, Hassett AC, Ragni1 MV, Isenberg JS and, Gladwin MT. Thrombospondin-1 inhibits ADAMTS13 activity in sickle cell disease. Haematologica November 1, 2013; 98 (11): e132-e134.. http://dx.doi.org/10.3324/haematol.2013.092635

27. Bottomley MJ1, Webb NJ, Watson CJ, Holt L, Bukhari M, Denton J, Freemont AJ, Brenchley PE. PIGF induces vascular endothelial growth factor (VEGF) secretion from mononuclear cells and is coexpressed with VEGF in synovial fluid. Clin Exp Immunol. 2000 Jan; $\quad 119: \quad 182-188 . \quad$ http://dx.doi.org/10.1046/j.13652249.2000.01097.x PMid:10606981 PMCid:PMC1905543

28. Nitin Patel, Caryn S. Gonsalves, Minyang Yang, Punam Malik, and Vijay K. Kalra : Placenta growth factor induces 5lipoxygenase-activating protein to increase leukotriene formation in sickle cell disease. Blood 2009; 113 (5):1129-1138 http://dx.doi.org/10.1182/blood-2008-07-169821 PMid:18945963 PMCid:PMC2635078

29. Patel N, Sundaram N, Yang M, Madigan C, Kalra VK, Malik P. Placenta growth factor (PlGF), a novel inducer of plasminogen activator inhibitor-1 (PAI-1) in sickle cell disease (SCD). J Biol Chem. 2010 May 28; 285(22):16713-22. doi: Epub 2010 Mar 29 http://dx.doi.org/10.1074/jbc.M110.101691

30. Wun T, Cordoba M, Rangaswami A, Cheung AW, Paglieroni T. Activated monocytes and platelet-monocyte aggregates in patients with sickle cell disease. Clin Lab Haematol. 2002 Apr; 24: 81-88. http://dx.doi.org/10.1046/j.1365-2257.2002.t01-1-00433.x PMid:11985552

31. Turhan A, Weiss LA, Mohandas N, Coller BS, Frenette PS. Primary role for adherent leukocytes in sickle cell vascular occlusion: a new paradigm. Proc Natl Acad Sci U S A. 2002 Mar; 99: 3047-3051. http://dx.doi.org/10.1073/pnas.052522799 PMid:11880644 PMCid:PMC122470

32. Britain JE, Hulkower B, Jones SK, Strayhorn D, De Castro L, Telen MJ, Orringer EP, Hinderliter A, Ataga KI. Placenta growth factor in sickle cell disease: association with hemolysis and inflammation. Blood 2010 Mar 11; 115 (10):2014-2020. Epub 2009 Dec 29. http://dx.doi.org/10.1182/blood-2009-04-217950

33. K Gupta, J Zhang Angiogenesis: a curse or cure? Postgrad Med J 2005; 81:236-242. http://dx.doi.org/10.1136/pgmi.2004.023309 